\title{
MEWUJUDKAN MANUSIA INDONESIA YANG UNGGUL MELALUI PEMENUHAN HAK-HAK ANAK DALAM KELUARGA
}

\begin{tabular}{|c|c|}
\hline & $\begin{array}{l}\text { Hani Sholihah } \\
\text { Sekolah Tinggi Agama Islam NU Tasikmalaya }\end{array}$ \\
\hline Keyword & \multirow{11}{*}{$\begin{array}{l}\text { Abstrac } \\
\text { Children are the next generation of the nation who will continue the } \\
\text { tasks and functions of the life relay of the previous generation. A child } \\
\text { has rights that must be fulfilled and protected. However, in reality } \\
\text { there are many cases of violence against children, often the } \\
\text { perpetrators are people who are supposed to protect them, namely } \\
\text { parents. Parenting in the family is very influential on the formation of } \\
\text { the character and character of children. Therefore, this paper aims to } \\
\text { examine efforts to realize superior Indonesian people through the } \\
\text { fulfillment of children's rights in the family. With library research } \\
\text { methods and normative juridical approaches, the data sources used are } \\
\text { secondary data sources in the form of legal materials, both primary, } \\
\text { secondary, and tertiary. The results of the study indicate that realizing } \\
\text { superior Indonesian people can be started from the fulfillment of } \\
\text { children's rights in the family. The use of good family parenting, } \\
\text { namely democratic parenting (authoritative) will shape the character, } \\
\text { character, and competence of children who are good and superior, so } \\
\text { that they become superior Indonesian people who are ready to } \\
\text { continue the legacy of the nation's leadership in the future. }\end{array}$} \\
\hline Children's Rights & \\
\hline Child protection & \\
\hline Family & \\
\hline & \\
\hline Corresponding Author & \\
\hline Hani Sholihah & \\
\hline STAINU Tasikmalaya & \\
\hline Indonesia & \\
\hline & \\
\hline & \\
\hline
\end{tabular}

\begin{abstract}
Abstrak
Anak adalah generasi penerus bangsa yang akan melanjutkan tugas dan fungsi estafeta kehidupan generasi sebelumnya. Seorang anak mempunyai hak yang harus dipenuhi dan dilindungi. Akan tetapi, dalam kenyataan banyak terjadi kasus kekerasan terhadap anak, yang tidak jarang pelakunya adalah orang yang seharusnya melindungi, yaitu orang tua. Pola asuh dalam keluarga sangat berpengaruh terhadap pembentukan watak dan karakter anak. Oleh karena itu, tulisan ini bertujuan untuk mengkaji upaya mewajudkan manusia Indonesia yang unggul melalui pemenuhan hak-hak anak dalam keluarga. Dengan metode penelitian pustaka dan pendekatan yuridis normatif, sumber data yang digunakan adalah sumber data sekunder berupa bahan-bahan hukum, baik yang primer, sekunder, maupun tertier. Hasil penelitian menunjukkan bahwa mewujudkan manusia Indonesia yang unggul dapat dimulai dari pemenuhan hak-hak anak dalam keluarga. Penggunaan pola asuh keluarga yang baik, yaitu pola asuh demokratis (authoritative) akan membentuk watak, karakter, dan kompetensi anak yang baik dan unggul, sehingga menjadi manusia Indonesia unggul yang siap melanjutkan estafeta kepemimpinan bangsa di masa yang akan datang.
\end{abstract}

Kata Kunci: Hak-hak Anak, Perlindungan Anak, Keluarga 


\section{PENDAHULUAN}

Anak adalah generasi penerus bangsa yang akan melanjutkan tugas dan fungsi estafeta kehidupan generasi sebelumnya, yaitu orang tua mereka. Masa depan suatu bangsa terletak pada generasi yang akan datang, yang sekarang masih termasuk kelompok anak-anak. Untuk itu, perlindungan dan pemenuhan hak-hak anak mutlak diperlukan untuk menjamin tumbuh kembang anak yang baik, sehingga melahirkan generasi yang siap memikul tanggung jawab dalam melanjutkan estafeta kehidupan pada masa yang akan datang. Dengan kata lain, perlu diupayakan terciptanya kesejahteraan anak, yaitu terpenuhinya segala hak dan kebutuhan hidup anak (Fitri et al., 2015).

Beberapa pemberitaan di berbagai media massa menyatakan masih banyaknya terjadi kekerasan terhadap anak dan masih banyak hak-hak anak yang belum terpenuhi. Perlakuan kasar terhadap anak, perkosaan, eksploitasi anak, dan tidak terpenuhinya hak pendidikan anak merupakan sebagian bentuk kekerasan terhadap anak dan belum terpenuhinya hak anak untuk memperoleh perlindungan. Kenyataan ini merupakan sesuatu yang cukup memprihatinkan (Laurensius Arliman S, 2016).

Pemerintah Indonesia sudah melakukan berbagai upaya untuk melindungi hak-hak anak. Berbagai produk peraturan perundang-undangan telah dibuat sebagai payung hukum pemerintah melakukan upaya perlindungan anak tersebut. Di samping itu, pembentukan Komisi Perlindungan Anak Indonesia juga merupakan salah satu upaya pemerintah dalam menjamin terpenuhinya hak-hak anak Indonesia. Namun dalam kenyataan di masyarakat, pelanggaran terhadap hak-hak anak masih tetap terjadi (Said, 2018), bahkan terdapat kecenderungan meningkat (Adawiah, 2015). Bentuk kekerasan terhadap anak paling tidak dapat dikelompokkan menjadi: 1) kekerasan fisik; 2) kekerasan psikis; 3) kekerasan seksual; 4) kekerasan ekonomi (Rozak, 2013).

Berbagai penelitian tentang perlindungan dan pemenuhan hak-hak anak telah banyak dilakukan. Di antara penelitian tersebut ada yang melakukan kajian perlindungan anak dengan pendekatan dari aspek hak asasi manusia (Laurensius Arliman S, 2016; Nugroho, 2017; Said, 2018), ada juga yang melakukan kajian dari aspek peraturan perundang-undangan (Prameswari, 2017). Beberapa hasil penelitian juga menemukan bahwa peran orang tua sangat signifikan dalam mencegah terjadinya perundungan terhadap anak (Anjelina et al., 2020). Dalam beberapa kasus, kekerasan terhadap anak dilakukan justru oleh orang tuanya sendiri. Salah satu faktor penyebab terjadinya perundungan orang tua terhadap anaknya adalah karena pemahaman agama yang kurang (Fitriana et al., 2015). Padahal, orang tua memegang peran yang sangat penting dalam pendidikan anak (Munita Sandarwati, 2014; Yuliharti, 2011). Orang tua merupakan agen pertama pembentukan karakter anak. Oleh karena itu, hendaknya orang tua menjadi contoh teladan bagi anak (Irmalia, 2020).

Penelitian ini bertujuan untuk mengkaji upaya mewujudkan sumber daya manusia Indonesia yang unggul melalui pemenuhan hak-hak anak dalam keluarga. Hal ini penting dilakukan karena anak merupakan generasi masa depan bangsa yang akan melanjutkan estafeta kepemimpinan di masa yang akan datang. Perlindungan dan pemenuhan hak-hak anak juga dapat dimulai dari keluarga sebagai unit terkecil dalam masyarakat. Oleh karena itu, membangun sumber daya manusia yang unggul, untuk membangun bangsa yang unggul, dapat dimulai dari keluarga. Dengan perlindungan dan pemenuhan hak-hak anak dalam keluarga, diharapkan akan terwujud anak-anak yang tangguh sebagai sumber daya manusia Indonesia unggul di masa depan.

\section{METODE}

Metode yang digunakan dalam penelitian ini adalah studi pustaka, yaitu dengan mengkaji berbagai referensi yang relevan dengan permasalahan yang diteliti. Pendekatan yang digunakan dalam penelitian ini adalah pendekatan yuridis normatif. 
Oleh karena itu, sumber data dalam penelitian ini merupakan sumber data sekunder, yang meliputi: 1) bahan hukum primer, yaitu peraturan perundang-undangan yang berkaitan dengan perlindungan dan pemenuhan hak-hak anak, yaitu Undang-Undang Nomor 35 Tahun 2014 tentang Perubahan atas Undang-Undang Nomor 23 Tahun 2002 tentang Perlindungan Anak; 2) bahan hukum sekunder, yaitu berbagai tulisan yang menjelaskan bahan hukum primer, seperti hasil-hasil penelitian dan karya tulis para ahli hukum; 3) bahan hukum tertier, yaitu bahan hukum yang memberikan penjelasan terhadap bahan hukum primer dan sekunder, seperti kamus, ensiklopedi, berbagai informasi dalam media elektronik, dan lain-lain. Data-data dari bahan hukum tersebut kemudian dikaji dan dianalisis, sehingga diperoleh sutu kesimpulan sesuai tujuan penelitian ini, yaitu mewujudkan sumber daya manusia Indonesia yang unggul melalui pemenuhan hak-hak anak dalam keluarga.

\section{HASIL}

\section{Perlindungan dan Pemenuhan Hak-Hak Anak}

Anak adalah seseorang yang belum berusia delapan belas tahun, termasuk anak yang masih dalam kandungan (Indonesia, 2002, 2014). Sebagai manusia, seorang anak mempunyai hak-hak dasar yang harus dipenuhi. Setiap anak berhak untuk dapat hidup, tumbuh, berkembang, dan berpartisipasi secara wajar sesuai dengan harkat dan martabat kemanusiaan, serta mendapat perlindungan dari kekerasan dan diskriminasi (Indonesia, 2002, 2014). Kondisi fisik maupun mental anak yang masih lemah, menjadikan anak rentan terhadap tindak kekerasan dan perlakuan salah lainnya (Arifiani et al., 2019). Untuk itu, perlu dilakukan upaya perlindungan anak, yaitu segala kegiatan untuk menjamin untuk melindungi anak dan hak-haknya, agar dapat hidup, tumbuh, berkembang, dan berpartisipasi secara optimal sesuai dengan harkat dan martabat kemanusiaan, serta mendapat perlindungan dari kekerasan dan diskriminasi (Indonesia, 2014).

Undang-Undang Nomor 35 Tahun 2014 tentang Perubahan atas Undang-Undang Nomor 23 Tahun 2002 tentang Perlindungan Anak menguraikan hak-hak anak dalam berbagai aspek kehidupan. Hak-hak anak tersebut (termasuk anak disabilitas dan berkebutuhan khusus) mencakup seluruh aspek kehidupan, yang meliputi bidang agama, sosial, pendidikan, kesehatan, hukum, informasi, dan komunikasi. Di samping itu, seorang anak juga berhak untuk memperoleh perlindungan dari perlakuan salah seperti diskriminasi, eksploitasi, penelantaran, kekejaman, kekerasan, dan penganiayaan, serta ketidakadilan dan perlakuan salah lainnya (Sholihah, 2018).

Undang-Undang tersebut juga menyatakan bahwa penyelenggara perlindungan anak adalah orang tua, keluarga, masyarakat, pemerintah, pemerintah daerah, dan negara. Kelima pilar penyelenggara perlindungan anak tersebut saling berkaitan dan harus saling mendukung karena upaya perlindungan dan pemenuhan hak-hak anak meliputi berbagai aspek kehidupan yang melibatkan kelima pilar penyelenggara perlindungan anak tersebut (Fitriani, 2016). Meskipun demikian, penelitian ini memfokuskan kajiannya pada upaya perlindungan dan pemenuhan hak-hak anak dalam keluarga, karena keluarga merupakan unit terkecil dalam masyarakat. Keluarga merupakan tempat pertama dan utama dalam tumbuh kembang anak (Munita Sandarwati, 2014). Jika setiap keluarga sudah dapat mewujudkan perlindungan dan pemenuhan hak-hak anak, maka akan terwujud masyarakat dan bangsa yang juga mewujudkan upaya perlindungan dan pemenuhan hak-hak anak.

Menurut Undang-Undang Perlindungan Anak, setiap anak berhak untuk: 1) hidup, tumbuh, berkembang, dan berpartisipasi secara wajar sesuai dengan harkat dan martabat kemanusiaan, serta mendapat perlindungan dari kekerasan dan diskriminasi; 2) berhak atas suatu nama sebagai identitas diri dan status kewarganegaraan; 3) beribadah menurut 
agamanya, berpikir, dan berekspresi sesuai dengan tingkat kecerdasan dan usianya, dalam bimbingan orang tua; 4) mengetahui orang tuanya, dibesarkan dan diasuh oleh orang tuanya sendiri; 5) diasuh atau diangkat sebagai anak asuh atau anak angkat oleh orang lain sesuai dengan ketentuan peraturan perundang-undangan yang berlaku; 6) memperoleh pelayanan kesehatan dan jaminan sosial sesuai dengan kebutuhan fisik, mental, spiritual, dan sosial; 7) memperoleh pendidikan dan pengajaran dalam rangka pengembangan pribadinya dan tingkat kecerdasannya sesuai dengan minat dan bakatnya; 8) memperoleh pendidikan luar biasa, selain pendidikan dan pengajaran bagi anak pada umumnya, bagi anak yang menyandang cacat; sedangkan bagi anak yang memiliki keunggulan juga berhak mendapatkan pendidikan khusus; 9) menyatakan dan didengar pendapatnya, menerima, mencari, dan memberikan informasi sesuai dengan tingkat kecerdasan dan usianya demi pengembangan dirinya, sesuai dengan nilai-nilai kesusilaan dan kepatutan; 10) beristirahat dan memanfaatkan waktu luang, bergaul dengan anak yang sebaya, bermain, berekreasi, dan berkreasi sesuai dengan minat, bakat, dan tingkat kecerdasannya demi perkembangan diri; 11) anak yang menyandang cacat berhak memperoleh rehabilitasi, bantuan sosial, dan pemeliharaan taraf kesejahteraan sosial; 12) selama dalam pengasuhan orang tua, wali, atau pihak lain manapun yang bertanggung jawab atas pengasuhan, seorang anak berhak mendapat perlindungan dari perlakuan: a) diskriminasi; b) eksploitasi, baik ekonomi maupun seksual; c) penelantaran; d) kekejaman, kekerasan, dan penganiayaan; e) ketidakadilan; f) perlakuan salah lainnya; 13) berhak untuk diasuh oleh orang tuanya sendiri, kecuali jika ada alasan dan/atau aturan hukum yang sah menunjukkan bahwa pemisahan itu adalah demi kepentingan terbaik bagi anak dan merupakan pertimbangan terakhir; 14) memperoleh perlindungan dari: a) penyalahgunaan dalam kegiatan politik; b) pelibatan dalam sengketa bersenjata; c) pelibatan dalam kerusuhan sosial; d) pelibatan dalam peristiwa yang mengandung unsur kekerasan; e) pelibatan dalam peperangan; 15) memperoleh perlindungan dari sasaran penganiayaan, penyiksaan, atau penjatuhan hukuman yang tidak manusiawi; 16) memperoleh kebebasan sesuai dengan hukum; penangkapan, penahanan, atau tindak pidana penjara anak hanya dilakukan apabila sesuai dengan hukum yang berlaku dan hanya dapat dilakukan sebagai upaya terakhir; 17) setiap anak yang dirampas kebebasannya berhak untuk: a) mendapatkan perlakuan secara manusiawi dan penempatannya dipisahkan dari orang dewasa; b) memperoleh bantuan hukum atau bantuan lainnya secara efektif dalam setiap tahapan upaya hukum yang berlaku; c) membela diri dan memperoleh keadilan di depan pengadilan anak yang objektif dan tidak memihak dalam sidang tertutup untuk umum; 18) setiap anak yang menjadi korban atau pelaku kekerasan seksual atau yang berhadapan dengan hukum berhak dirahasiakan; 19) setiap anak yang menjadi korban atau pelaku tindak pidana berhak mendapatkan bantuan hukum dan bantuan lainnya (Indonesia, 2014).

\section{Mewujudkan Manusia Unggul melalui Pemenuhan Hak-Hak Anak dalam Keluarga}

Keluarga merupakan unit terkecil dalam masyarakat dan menjadi salah satu pilar eksistensi suatu bangsa. Keluarga memegang peran yang sangat penting dalam membangun karakter para anggotanya, khususnya anak-anak, dalam berbagai aspek kehidupan. Dalam keluarga ditanamkan nilai-nilai pendidikan dan pengajaran, karakter, keagamaan, dan nilai-nilai sosial kemasyarakatan. Keluarga merupakan tempat pertama dan utama pendidikan anak-anak (Ashari et al., 2019). Bagi anak-anak, keluarga merupakan tempat belajar yang utama dan pertama (Andriyani, 2016). Orang tua memegang peran yang sangat penting dalam pendidikan anak (Munita Sandarwati, 2014; Yuliharti, 2011). 
Keluarga merupakan tempat pertama proses pembentukan karakter seorang anak. Proses tersebut terjadi melalui internalisasi nilai-nilai yang timbul dari perasaan, perhatian sikap, dan perilaku keseharian orang tua (Hasanah, 2016). Peran orang tua dalam proses pembentukan karakter anak sangat besar. Orang tua mempunyai peran dan tanggung jawab yang besar dalam mengembangkan potensi anak. Fungsi dan peran orang tua terhadap anaknya tidak hanya mencakup kebutuhan fisik saja, melinkan juga meliputi perhatian, kasih sayang, motivasi, bimbingan, arahan, pendidikan, dan penanaman nilai-nilai kebaikan (akhlak) (Jailani, 2014).

Pola asuh yang dipakai orang tua dalam mendidik anaknya akan berpengaruh terhadap kepribadian anak di semua aspek kehidupannya. Hasil penelitian menunjukkan bahwa pola asuh orang tua berpengaruh terhadap prestasi anak di sekolah. Pola asuh orang tua yang baik (yaitu pola asuh otoritatif) berpengaruh terhadap prestasi anak yang bagus di sekolah (Efobi \& Nwokolo, 2014; Nyarko \& Lg, 2011). Sebaliknya, pola asuh orang tua yang tidak baik (seperti pola asuh otoriter, permisif, dan tidak peduli) berpengaruh terhadap pembentukan karakter anak menjadi pribadi yang tidak baik. Bahkan, karena pola asuh yang tidak baik, anak menjadi pelaku kekerasan di sekolah (Efobi \& Nwokolo, 2014; Eşkisu, 2014). Pola asuh orang tua yang salah diperparah dengan ketidaksadaran mereka akan hal itu. Mereka tidak menyadari bahwa cara mereka dalam mendidik anak adalah salah. Misalnya, mereka mendidik dengan pola yang tidak disadari mengandung kekerasan, sehingga membentuk karakter anak yang cenderung menjadi pelaku kekerasan (Thohir, 2015).

Keluarga mempunyai lima fungsi dasar, yaitu: 1) reproduksi, yaitu melestarikan populasi yang terdapat dalam masyarakat; 2) sosialisasi dan edukasi, yaitu keluarga menjadi sarana trasformasi nilai-nilai, keyakinan, sikap, pengetahuan, keterampilan, dari generasi sebelumnya kepada generasi penerusnya; 3) penugasan peran sosial, yaitu memberikan identitas kepada para anggota keluarga, seperti ras, etnik, agama, sosial ekonomi, dan peran gender; 4) dukungan ekonomi, yaitu keluarga menjadi tempat berlindung, memenuhi kebutuhan makanan, dan pemenuhan kebutuhan hidup lainnya; 5) dukungan emosi dan pemeliharaan, yaitu keluarga memberikan pengalaman interaksi sosial yang pertama bagi anak, berupa interaksi yang mendalam, mengasuh, dan membangun daya tahan anak, sehingga memberikan rasa aman pada anak (Andriyani, 2016).

Dalam kaitannya dengan perlindungan anak, orang tua dan keluarga berkewajiban melakukan upaya perlindungan dan pemenuhan hak-hak anak. Orang tua harus mengetahui dan memahami bahwa perilaku penelantaran anak, baik emosional maupun verbal, termasuk dalam kekerasan terhadap anak. Apabila hal tersebut terus-menerus dilakukan orang tua, maka akan berdampak negatif terhadap perkembangan mental dan intelektual anak, yang pada akhirnya akan membentuk perilaku kenakalan pada masa remaja. Pengalaman diabaikan di masa kecil akan melekat pada jiwa anak. Setiap perlakuan salah terhadap anak akan membentuk perilaku mengabaikan sekitarnya pada masa dewasa anak tersebut. Semua tindakan kekerasan terhadap anak terekam di alam bawah sadar dan terbawa hingga dewasa, bahkan sepanjang hidupnya (Supaat \& Fa'atin, 2019).

Perhatian, kendali dan tindakan orang tua merupakan salah satu bentuk pola asuh yang akan memberikan dampak panjang terhadap kelangsungan perkembangan fisik dan mental anak. Pola asuh adalah suatu model perlakuan atau tindakan orang tua dalam membina dan membimbing serta memelihara anak agar dapat berdiri sendiri. Lebih dari itu pola asuh yang dipakai orang tua dalam keluarga akan membentuk watak dan karakter anak pada masa dewasanya. Masa kanak-kanak merupakan masa pembentukan watak dan karakter, serta penanaman nilai-nilai sosial dan agama. Perlakuan orang tua kepada anak-anaknya sejak masa kecil akan berdampak pada perkembangan sosial dan 


\section{SEMINAR NASIONAL DIES NATALIS KE-41 UNIVERSITAS TUNAS PEMBANGUNAN SURAKARTA}

moral pada masa dewasanya. Perkembangan sosial dan moral inilah yang akan membentuk watak, sifat dan sikap anak kelak, meskipun terdapat faktor lain yang berpengaruh dalam pembentukan sikap dan karakter anak. Secara teoritis, pola asuh yang dilakukan orang tua memiliki 3 jenis yang terdiri dari pola asuh otoriter, permisif dan otoritatif. Ketiga pola asuh itu memiliki pengaruh besar terhadap pembentukan kepribadian anak. Untuk itu, pola asuh orang tua sangat menentukan watak, sikap dan prilaku anak. Di sinilah pentingnya pendidikan keluarga dan pola asuh yang tepat yang dipakai keluarga dalam membentuk karakter anak-anak mereka (Anisah, 2011).

\section{PEMBAHASAN}

Pola asuh adalah pola sikap atau perlakuan orang tua terhadap anak yang akan berpengaruh terhadap perilaku dan karakter anak nantinya, baik terhadap kompetensi emosional, sosial, maupun intelektual. Menurut Baumrind, terdapat tiga pola asuh orang tua terhadap anak, yang masing-masing pola asuh tersebut memiliki kontribusi yang penting dalam pembentukan karakter anak. Ketiga pola asuh tersebut ialah authoritative, authoritarian, dan permissive. Orang tua yang menggunakan pola asuh authoritative akan memiliki sikap "acceptance" dan kontrol yang tinggi terhadap anak, bersikap responsif terhadap kebutuhan anak mereka, dan mendorong anak untuk menyatakan pendapat atau pertanyaan, serta memberikan penjelasan tentang dampak baik atau buruk suatu perbuatan. Pola asuh orang tua yang authoritative akan berdampak kepada kematangan emosi anak. Hal ini disebabkan anak yang diasuh dengan pola asuh authoritative akan me miliki kemampuan untuk menghindari konflik karena pola asuh orang tua yang selalu menjelaskan dampak suatu perbuatan, baik dan buruknya. Di samping itu, anak yang mendapatkan pola asuh ini akan mudah mengalirkan cinta dan kasih sayang kepada orang lain, karena sikap responsif dan "acceptance" yang diterima remaja dari kedua orang tuanya. Anak yang diasuh dengan pola asuh ini juga akan mampu berpikir positif dalam menghadapi setiap persoalan. Anak tersebut juga akan memiliki sikap optimis, berprestasi di sekolah, bertanggung jawab, serta lebih berkompeten dibandingkan teman-temannya (Fellasari \& Lestari, 2017).

Sementara itu, orang tua yang menggunakan pola asuh authoritarian akan memiliki sikap "acceptance" yang rendah, tetapi menerapkan kontrol yang tinggi terhadap anak, suka memberi hukuman fisik kepada anak, bersifat mengomando, bersikap kaku (keras), cenderung emosional, dan bersikap menolak. Pola asuh authoritarian ini akan berdampak kurang baik pada kemampuan anak dalam mengontrol emosi. Hal ini dikarenakan pola asuh yang diterima anak di rumah cenderung emosional dan keras, sehingga anak akan merasa tidak nyaman, mengalami tekanan, mudah mengalami stres, memiliki sikap pencemas, emosi yang tidak stabil, penakut, pendiam serta tertutup. Anak yang diasuh dengan menggunakan pola asuh authoritarian akan lebih mudah terpengaruh untuk melakukan pelanggaran norma karena tingkat kematangan emosinya yang sangat rendah. Anak tersebut akan susah mengontrol emosinya, kurang memiliki prestasi di sekolah, dan cenderung terjerumus ke dalam perilaku negatif. Di samping itu, anak tersebut mempunya potensi untuk tidak mudah mengalirkan cinta dan kasih sayang karena sikap kaku yang diterima anak dari kedua orang tuanya. Anak tersebut juga kurang dapat mengatur hidupnya untuk masa depan karena masa depan anak tersebut berada di tangan kedua orang tuanya (Fellasari \& Lestari, 2017).

Orang tua yang menerapkan pola asuh permissive akan memiliki sikap "acceptance" yang tinggi, tetapi kontrol mereka terhadap anak rendah, serta memberikan kebebasan kepada anak untuk menyatakan perasaan atau keinginannya. Pola asuh permissive yang diterapkan orang tua akan membuat anak memiliki kontrol emosi yang rendah dan terdapat kecenderungan memiliki perilaku agresif. Hal ini disebabkan kontrol orang tua yang rendah terhadap perilaku anak dan membuat anak tidak memiliki rasa takut untuk 
melanggar peraturan. Akibatnya, anak akan sering mengalami konflik, baik di sekolah, di rumah maupun di lingkungan masyarakat. Pola asuh permissive yang diterapkan orang tua juga membuat anak menjadi tidak patuh, manja, kurang mandiri dan mau menang sendiri. Jika kemudian anak tersebut dihadapkan pada kenyataan yang tidak sesuai dengan keinginannya, anak akan mudah memberontak, menangis dan meratapi kenyataan tersebut dan sulit untuk dapat menerimanya. Anak yang diasuh dengan menggunakan pola asuh permissive akan memiliki sikap suka memberontak, memiliki rasa pengendalian diri yang rendah, tidak jelas arah hidupnya dan kurang percaya diri (Fellasari \& Lestari, 2017).

Berdasarkan pembagian ketiga pola asuh orang tua tersebut, yaitu pola asuh authoritative, authoritarian, dan permissive, pola asuh authoritative merupakan pola asuh yang dapat menumbuhkan sikap kematangan emosi pada anak. Adapun pola asuh authoritarian dan permissive merupakan pola asuh yang kurang dapat menumbuhkan sikap kematangan emosi anak pada masa dewasanya. Dengan demikian, dapat dikatakan bahwa pola asuh yang diterapkan orang tua di rumah akan sangat berdampak pada perilaku, karakter, dan kematangan emosi anak di masa depan. Kematangan emosi dapat diperoleh jika keluarga memberikan kasih sayangnya kepada anak. Dengan kasih sayang, anak akan merasa nyaman dan jauh dari perilaku negatif. Sebaliknya, ketidakmatangan emosi akan terjadi jika orangtua bersikap acuh tak acuh dan memaksakan kehendaknya kepada anak. Hal tersebut akan membuat anak merasa tertekan dan menjadi mudah marah (Fellasari \& Lestari, 2017).

Kematangan emosional anak juga berpengaruh terhadap perkembangan kognitif anak. Hasil penelitian mencatat ketidakmungkinan perkembangan kognitif anak tanpa keterampilan sosio-emosional. Perkembangan sosio-emosional adalah pembentukan dan perkembangan nilai-nilai sosial, yang merupakan ciri-ciri kepribadian yang penting dimiliki seseorang untuk menguasai hal-hal berikut: berbagai cara merespon dan mengendalikan emosi, kemampuan untuk mengenali emosinya sendiri dan mengendalikannya dalam situasi kehidupan yang berbeda, serta pembentukan dan pemeliharaan kontak emosional dengan orang lain. Perkembangan emosional seorang anak terjadi dalam beberapa cara: mengatasi perilaku impulsif, munculnya emosi yang stabil di samping yang situasional, mengembangkan kemampuan menggunakan ekspresi emosi sebagai sarana komunikasi dan mengenali emosi berdasarkan ekspresi wajah. Kematangan sosio-emosional juga dapat diukur dengan kriteria kehangatan emosional, kemampuan untuk terlibat dalam hubungan, kemampuan berpikir kreatif, dan kemampuan komunikasi yang bermakna. Intinya, kematangan sosio-emosional sangat berpengaruh terhadap keterampilan komunikatif dan kognitif (Lavrova et al., 2018).

Pendidikan dan pola asuh yang diterapkan dalam keluarga sangat berpengaruh terhadap perkembangan karakter anak-anak mereka. Pola asuh orang tua berpengaruh terhadap watak, sikap, dan perilaku anak, serta kemampuan pengendalian diri anak (Anisah, 2011). Orang tua yang menerapkan pola asuh yang baik akan membuat anakanak mereka berperilaku sosial yang lebih baik. Hasil penelitian menunjukkan bahwa terdapat korelasi positif antara pola asuh orang tua dan kecerdasan emosional anak. Penelitian tersebut juga menunjukkan bahwa pola asuh yang paling baik adalah pola asuh demokratis (authoritative) (Ashari et al., 2019). Penelitian lain menyatakan bahwa pola asuh orang tua berpengaruh terhadap prestasi anak di sekolah. Pola asuh orang tua yang baik (yaitu pola asuh otoritatif) berpengaruh terhadap prestasi anak yang bagus di sekolah. Sebaliknya, pola asuh orang tua yang tidak baik berpengaruh terhadap pembentukan karakter anak menjadi pribadi yang tidak baik (Efobi \& Nwokolo, 2014; Nyarko \& Lg, 2011).

Keluarga memegang peran yang sangat penting dalam membangun generasi penerus yang baik. Karakter anak sebagai generasi penerus ditentukan oleh pola asuh orang tua 
dalam keluarga. Keluarga sangat berperan penting dalam proses pendidikan anak-anak. Perilaku anak sangat dipengaruhi oleh bagaimana interaksi dan relasi yang terjalin dalam keluarga. Relasi (hubungan) yang baik dalam keluarga berpengaruh besar terhadap kematangan sikap mental anak. Komunikasi yang terjalin dalam keluarga merupakan proses seorang anak menerima pengetahuan nilai-nilai. Fase awal dalam keluarga ini akan menjadi referensi kepribadian anak pada masa selanjutnya. Oleh karena itu, keluarga (orang tua) hendaknya mengajarkan dan merealisasikan nilai-nilai positif agar kepribadian anak terbina dengan baik (Andriyani, 2016). Bahkan, bukan hanya perilaku, cara pandang orang tua terhadap anaknya juga berpengaruh terhadap perkembangan pribadi anak (Muntoni \& Retelsdorf, 2019).

\section{SIMPULAN}

Pola asuh orang tua terhadap anak mereka dalam keluarga sangat berdampak terhadap pembentukan watak dan karakter anak, serta berpengaruh juga terhadap kemampuan kognitif dan pengendalian emosi anak. Di samping itu, pola asuh keluarga yang baik, seperti dalam pola asuh authoritative, dapat menjadikan anak sebagai pribadi yang unggul, yang sangat diperlukan dalam fungsinya sebagai generasi penerus bangsa. Pola asuh keluarga yang baik juga mengandung arti keluarga yang mampu memenuhi hak-hak anak dan memberikan perlindungan terhadap anak dari berbagai tindakan kekerasan dan perilaku salah lainnya. Dengan demikian, dapat disimpulkan bahwa membangun sumber daya manusia Indonesia yang unggul dapat dimulai dari pemenuhan hak-hak anak dalam keluarga, dengan penggunaan pola asuh keluarga yang baik, yang akan membentuk watak, karakter, dan kompetensi anak yang baik dan unggul. Temuan penelitian ini dapat ditindaklanjuti dengan penelitian lapangan yang diharapkan akan dapat lebih memperkuat simpulan penelitian ini.

\section{DAFTAR PUSTAKA}

Adawiah, R. Al. (2015). Upaya Pencegahan Kekerasan terhadap Anak. Jurnal Keamanan Nasional, 1(2), 279-296.

Andriyani, J. (2016). Korelasi Peran Keluarga terhadap Penyesuaian Diri Remaja. AlBayan, 22(34), 39-52. http://www.e-psikologi.com/remaja/160802.htm

Anisah. (2011). Pola Asuh Orang Tua dan Implikasinya terhadap Pembentukan Karakter Anak. Jurnal Pendidikan Universitas Garut, 5(1), 70-84.

Anjelina, L., Putri, D., Yetti, E., \& Hartati, S. (2020). Pengaruh Keterlibatan Orangtua dan Regulasi Diri terhadap Perilaku Bullying Anak Usia Dini. Jurnal Obsesi: Jurnal Pendidikan Anak Usia Dini, 4(1), 715-732. https://doi.org/10.31004/obsesi.v4i2.438

Arifiani, S. D., Handayani, S. A., Baumont, M., Bennouna, C., \& Kusumaningrum, S. (2019). Assessing large-scale violence against children surveys in selected Southeast Asian countries: A scoping review. Child Abuse and Neglect, 93(December 2018), 149-161. https://doi.org/10.1016/j.chiabu.2019.05.005

Ashari, M., Nurhayati, W., \& Purwanto, A. (2019). The Effect of Parenting Style and Genetic Personality on Children Character Development. Jurnal Penelitian Dan Evaluasi Pendidikan, 23(2). https://doi.org/10.21831/pep,v23i2.28151

Efobi, A., \& Nwokolo, C. (2014). Relationship between Parenting Styles and Tendency to Bullying Behaviour among Adolescents. Journal of Education \& Human Development, 3(1), 507-521.

Eşkisu, M. (2014). The Relationship between Bullying, Family Functions, Perceived Social Support among High School Students. Procedia - Social and Behavioral Sciences, 159, 492-496. https://doi.org/10.1016/j.sbspro.2014.12.412

Fellasari, F., \& Lestari, Y. I. (2017). Hubungan antara Pola Asuh Orangtua dengan 
Kematangan Emosi Remaja. Jurnal Psikologi, 12(2), 84. https://doi.org/10.24014/jp.v12i2.3234

Fitri, A. N., Riana, A. W., \& Fedryansyah, M. (2015). Perlindungan Hak-Hak Anak dalam Upaya Peningkatan Kesejahteraan Anak. Prosiding Penelitian Dan Pengabdian Kepada Masyarakat, 2(1), 45-50. https://doi.org/10.24198/jppm.v2i1.13235

Fitriana, Y., Pratiwi, K., \& Sutanto, A. V. (2015). Faktor-Faktor yang Berhubungan dengan Perilaku Orang Tua dalam Melakukan Kekerasan Verbal terhadap Anak Usia Pra-Sekolah. Jurnal Psikologi Undip, 14(1), 81-93. https://doi.org/10.14710/jpu.14.1.81-93

Fitriani, R. (2016). Peranan Penyelenggara Perlindungan Anak dalam Melindungi dan Memenuhi Hak-Hak Anak. Jurnal Hukum Samudra Keadilan, 11(2), 250-358.

Hasanah, N. (2016). Parents' Expectations of the Teaching and Learning Islamic Education. Jurnal Pendidikan Islam, 2(2), 254. https://doi.org/10.15575/jpi.v2i2.789

Indonesia, R. (2002). Undang-Undang Nomor 23 Tahun 2002.

Indonesia, R. (2014). Undang-Undang No. 35 Tahun 2014.

Irmalia, S. (2020). Peran Orang Tua dalam Pembentukan Karakter Anak Usia Dini. Jurnal El-Hamra. https://doi.org/10.1017/CBO9781107415324.004

Jailani, M. S. (2014). Teori Pendidikan Keluarga dan Tanggung Jawab Orang Tua dalam Pendidikan Anak Usia Dini. Nadwa, Jurnal Pendidikan Islam, 8.

Laurensius Arliman S. (2016). Peranan Filsafat Hukum dalam Perlindungan Hak Anak yang Berkelanjutan sebagai Bagian dari Hak Asasi Manusia. Doctrinal, 1(2).

Lavrova, M., Tokarskaya, L., \& Kiselev, S. (2018). Influence of Parent-Child Interaction on Socio-emotional Development of Children with Perinatal Risks. KnE Life Sciences, 2018, 531-543. https://doi.org/10.18502/kls.v4i8.3311

Munita Sandarwati, E. (2014). Revitalisasi Peran Orang Tua dalam Mengurangi Tindak Kekerasan terhadap Anak. Sawwa: Jurnal Studi Gender, 9(2), 287. https://doi.org/10.21580/sa.v9i2.637

Muntoni, F., \& Retelsdorf, J. (2019). At Their Children's Expense: How Parents' Gender Stereotypes Affect Their Children's Reading Outcomes. Learning and Instruction, 60(November 2018), 95-103. https://doi.org/10.1016/j.learninstruc.2018.12.002

Nugroho, O. C. (2017). Peran Balai Pemasyarakatan pada Sistem Peradilan Pidana Anak Ditinjau dalam Perspektif Hak Asasi Manusia. Jurnal HAM, 8(2), 161. https://doi.org/10.30641/ham.2017.8.356

Nyarko, K., \& Lg, P. O. B. (2011). The influence of authoritative parenting style on adolescents academic achievement. 278-282. https://doi.org/10.5251/ajsms.2011.2.3.278.282

Prameswari, Z. W. A. W. (2017). Ratifikasi Konvensi tentang Hak-Hak Anak dalam Sistem Peraturan Perundang-Undangan di Indonesia. Yuridika, 32(1), 167. https://doi.org/10.20473/ydk.v32i1.4842

Rozak, P. (2013). Kekerasan terhadap Anak dalam Rumah Tangga Perspektif Hukum Islam. Sawwa, 9, 45-70.

Said, M. F. (2018). Perlindungan Hukum terhadap Anak dalam Perspektif Hak Asasi $\begin{array}{lllll}\text { Manusia. JCH (Jurnal Cendekia Hukum), } & 4(1), & 141 .\end{array}$ https://doi.org/10.33760/jch.v4i1.97

Sholihah, H. (2018). Perbandingan Hak-hak Anak menurut Undang- Undang Nomor 23 Tahun 2002 tentang Perlindungan Anak dan Hukum Islam. Al-Afkar, Journal for Islamic Studies, 1(2), 88-111. https://doi.org/10.5281/zenodo.3554863

Supaat, S., \& Fa'atin, S. (2019). The Muslim Millennial Family Typology: The Role of 
Muslim Family Circumflex Model to Avoid Parents' Violent Behavior Against Children in Indonesia. Indonesian Journal of Islam and Muslim Societies, 9(1), 57. https://doi.org/10.18326/ijims.v9i1.57-81

Thohir, M. (2015). Radikalisme Versus Pendidikan Agama Menggali Akar Radikalisme dari Kekerasan terhadap Anak atas Nama Pendidikan Agama. Nadwa, Jurnal Pendidikan Islam, 9, 167-182.

Yuliharti, Y. (2011). Peranan Orang Tua dalam Pendidikan Agama Anak Usia Dini. Marwah: Jurnal Perempuan, Agama Dan Jender, 10(1), 48. https://doi.org/10.24014/marwah.v10i1.485 